\title{
PENGARUH KELAS IBU HAMIL TERHADAP \\ PENGETAHUAN, SIKAP, DAN PERSEPSI KECEMASAN IBU \\ HAMIL DALAM MENGHADAPI PERSALINAN DI BPS "N", MANIS HARJO, SEMARANG UTARA TAHUN 2010
}

\author{
Oleh : \\ Umriaty \\ Dosen Program Studi Kebidanan \\ Politeknik Harapan Bersama
}

\begin{abstract}
Abstrak
Kelas ibu hamil merupakan salah satu kegiatan penting dalam penerapan buku KIA di masyarakat sebagai upaya pembelajaran ibu, suami dan keluarga melalui kegiatan belajar bersama untuk mempersiapkan ibu hamil dalam meghadapi persalinan yang aman dan selamat. Rancangan peneliti yang digunakan adalah Quasi Experimental Desaing Pre Test Post Test Group yaitu penelitian eksperimental yang tidak sebenarnya. Dalam penelitian ini subyek penelitian adalah ibu hamil dengan umur kehamilan 20-32 minggu pada bulan juni 2010. Uji validitas dihitung dengan menggunakan rumus Pearson Product Moment $\left(\mathrm{r}_{\mathrm{xy}}\right)$ sedangkan uji reliabilitas dilakukan dengan menggunakan Cronbach Alpha. Hasil penelitian menunjukan adanya pengaruh kelas ibu hamil terhadap pengetahuan yang dilihat perbedaan pengukuran pengetahuan sebelum dan sesudah pelaksanaan kelas ibu hamil dengan nilai $\mathrm{Z}=-5,09$ dan nilai $\mathrm{p}=0,000$. hasil uji $\mathrm{T}$ test menunjukan ada perbedaan sikap pre test dan post test. beda rata-rata $-32,47$, nilai $t=-18,85$, nila $\mathrm{p}=0,000$, nilai $a=0,05$. Nilai negatif (-) artinya nilai post test lebih tinggi daripada nilai pretes. ini berarti hipotesis kerja (ha) di terima karena nilai $\mathrm{p}<\mathrm{a}$, artinya terdapat perbedaan sikap sebelum dan sesudah pelaksanaan kelas ibu hamil. Ada perbedaan kecemasan dalam menghadapi persalinan pre test dan post test. beda rata-rata 2,56 , nilai $t=9,68$, nilai $\mathrm{p}=0,000$, nilai $\mathrm{a}=0,05$.
\end{abstract}

Kata Kunci : Ibu Hamil, Eksperimental, Validitas, Reliabilitas, Pearson Product Moment, Cronbach Alpha 